\title{
APLIKASI PEMBELAJARAN AUDIT SISTEM INFORMASI DAN TATA KELOLA TEKNOLOGI INFORMASI BERBASIS MOBILE
}

\author{
Yuri Rahmanto $^{1)}$, Muhammad Farhan Randhika ${ }^{2)}$, Faruk Ulum ${ }^{3)}$, Bentar Priyopradono ${ }^{4)}$ \\ ${ }^{1)}$ Teknik Komputer, Universitas Teknokrat Indonesia \\ ${ }^{2), 3}{ }^{3}$ Sistem Informasi, Universitas Teknokrat Indonesia \\ ${ }^{4)}$ Informatika, Universitas Prof. Dr. Hazairin, SH \\ 1),2),3) Jl. H.ZA Pagaralam, No 9-11, Labuhanratu,Bandarlampung \\ 4) Jl. A. Yani No. 1 Kota Bengkulu \\ Email : yurirahmanto@teknokrat.ac.id ${ }^{1)}$,farhan.randhika@gmail.com ${ }^{2)}$,faruk.ulum@teknokrat.ac.id ${ }^{3)}$, \\ bentarpriyopradono@gmail.com ${ }^{4)}$
}

\begin{abstract}
Abstrak
Audit sistem informasi merupakan salah satu matakuliah yang diajarkan di dalam jurusan sistem informasi pada fakultas teknik dan ilmu komputer, matakuliah ini memberikan pemahaman dan pelaksanaan audit untuk sistem informasi berbasis komputer, sehingga pada akhirnya diharapkan mahasiswa dapat melaksanakan audit berbasis komputer, baik untuk hardware, software, maupun brainware, secara umum pada perusahaan.
\end{abstract}

Penting sekali bagi mahasiswa jurusan sistem informasi mempelajari matakuliah audit sistem informasi untuk dapat memahami dan mengerti setidaknya dasar dari materi tata kelola teknologi informasi, karena pada umumnya mahasiswa mempelajari materi ini melalui manual book dan proses belajar di kelas, sehingga dibutuhkan sebuah media pembelajaran yang dapat memudahkan mahasiswa dalam mempelajari matakuliah audit sistem informasi terkhusus pada materi IT Governance atau tata kelola teknologi informasi secara mandiri.

Penelitian ini menghasilkan sebuah rancangan interface Aplikasi pembelajaran audit sistem informasi dan tata kelola teknologi informasi berbasis mobile, dan sebuah instrumen penelitian yang telah diuji menggunakan uji statistik. Berdasarkan pengujian persepsi kemudahan didapatkan hasil bahwa rancangan interface aplikasi yang dibuat kurang memudahkan pengguna dalam pengoperasian dengan persentase $78 \%$ responden ragu terhadap aplikasi pembelajaran audit sistem informasi dan tata kelola teknologi informasi berbasis mobile ini.

Kata kunci: Audit Sistem Informasi, Aplikasi Pembelajaran, E-Learning, M-Learning.

\section{Pendahuluan}

Memasuki era dimana perkembangan teknologi yang sangat pesat ini, masyarakat dituntut untuk mengubah semua aspek dalam setiap kegiatan sehari-hari. Salah satu bidang yang terkena dampak dari perkembangan teknologi adalah pendidikan, yang dimana media pembelajaran merupakan hal yang telah diwajibkan pemerintahan Indonesia seperti yang tertera pada Peraturan Pemerintah No. 19 Tahun 2005 Pasal 1 Ayat 8, bahwasannya Teknologi Informasi dan Komunikasi (TIK), merupakan bagian dari standar dan prasarana yang diperlukan untuk menunjang proses pembelajaran.

Salah satu teknologi TIK yang berkembang di bidang pendidikan adalah teknologi mobile. Dengan munculnya teknologi mobile, paradigma baru dari pengajaran dan pembelajaran dengan bantuan teknologi telah muncul, yaitu mobile learning (m-learning) (Chee et al., 2017). M-learning sendiri berasal dari e-learning media pembelajaran yang bermanfaat pada dukungan dan peningkatan yang dibawa oleh penggunaan komputer dan beragam teknik komunikasi, sedangkan e-learning berasal dari distance learning (pembelajran jarak jauh) (Marghescu, Chicioreanu and Marghescu, 2007).

Berdasarkan penelitian Ozuorcun and Tabak (2012), Elearning dan m-learning memiliki 2 perbedaan utama, perbedaan pertama e-learning bersifat formal sementara m-learning bersifat informal, pada model formal pembelajaran didorang oleh entitas eksternal seperti individu, sekolah, perguruan tinggi, perusahaan, dan lain-lain, sementara informal pembelajaran terjadi secara alami tanpa dorongan eksternal sebagai konsekuensi dari seseorang yang termotivasi dan ingin belajar, sehingga model informal didorong atas kemauan sendiri.

Perbedaan kedua m-learning bersifat situated learning sehingga m-learning dapat mendukung pembelajaran elearning yang bersifat collaborative learning. Adapun perangkat mobile yang biasa digunakan terkait mlearning adalah Smartphone, Mobile Phone, Tablet PC, PDA dan sebagainya. Menurut Chee et al (2017) Smartphone saat ini merupakan perangkat yang paling sering digunakan dalam kegiatan m-learning, dan ratarata pengguna smartphone saat ini menggunakan smartphone berbasis platform Android.

Terdapat juga penelitian Mulyawan and Budiman (2013) yang menyimpulkan m-learning merupakan pembelajaran yang cukup prospektif dan viable. 
Kesimpulan tersebut memperkuat hasil penelitian yang dilakukan oleh Chee et al (2017) bahwasannya kebanyakan penelitian m-learning mendapatkan hasil yang positif. Oleh karena itu penulis mengambil konsep media pembelajaran m-learning sebagai dasar pembuatan aplikasi pembelajaran berbasis mobile.

Berdasarkan gambar 1, Chee et al (2017) menemukan trend penerapan m-learning pada bidang ilmu pengetahuan tertentu dari tahun 2010 hingga tahun 2015 , dimana didapatkan hasil bahwa, ilmu pengetahuan dibidang sciene, merupakan ilmu pengetahuan yang paling sering digunakan dalam penerapan m-leraning, akan tetapi jika kita melihat grafik, penerapan pada ilmu pengetahuan social sciene mengalami peningkatan yang drastis pada tahun 2014 hingga 2015, bahkan mengalahkan ilmu pengetahuan sciene, ini membuktikan bahwa kebutuhan akan m-learning pada bidang ilmu pengetahuan social sciene sangat diperlukan, dan salah satu matakuliah yang termasuk didalam ilmu pengetahuan dibidang ini ialah audit sistem informasi.

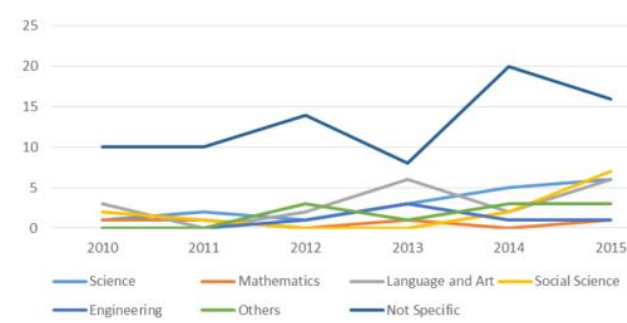

Gambar 1. Trend Ilmu Pengetahuan Yang Diterapkan Pada M-Learning

Sumber: Chee, K. N. et al. 2017 (Review of Mobile Learning Trends 2010-2015 : A Meta-Analysis)

Audit sistem informasi merupakan salah satu matakuliah yang diajarkan didalam jurusan sistem informasi pada fakultas teknik dan ilmu komputer Universitas Teknokrat Indonesia, matakuliah ini memberikan pemahaman dan pelaksanaan audit untuk sistem informasi berbasis komputer, sehingga pada akhirnya diharapkan mahasiswa dapat melaksanakan audit berbasis komputer, baik untuk hardware, software, maupun brainware, secara umum pada perusahaan. Setelah mempelajari Audit Sistem Informasi, maka mahasiswa dapat menjelaskan mengenai konsep audit sistem informasi/teknologi informasi, resiko-resiko, sistem pengendalian atau control yang sebaiknya diterapkan, dan pemeriksaan (audit) terhadap kualitas pengelolaan sistem informasi, pengembangan sistem aplikasi, dan pemeriksaan terhadap keterhandalan sistem aplikasi tertentu, dengan teknik audit yang dilaksanakan secara manual maupun dengan berbantuan komputer. Resikoresiko yang berkaitan dengan sistem berbasis komputer, mencakup resiko tidak efektif/efisien, ekonomisnya manajemen unit/fungsi sistem informasi, resiko kelemahan dalam system development, maupun resiko yang berkaitan dengan kurangnya kehandalan suatu aplikasi yang sudah di implementasikan (Universitas Teknokrat Indonesia, 2017).
Salah satu materi yang terdapat di matakuliah audit sistem informasi berdasarkan rancangan pembelajaran semester adalah tata kelola teknologi informasi atau IT Governance. Tata kelola teknologi informasi juga telah diatur dalam Peraturan Menteri Komunikasi dan Informatika Republik Indonesia Nomor 41/PER/MEN.KOMINFO/11/2007 dengan menetapkan Panduan Umum Tata Kelola Teknologi Informasi dan Komunikasi Nasional, ini menandakan bahwasannya pemerintahan Indonesia juga berpendapat IT Governance atau tata kelola teknologi informasi ini sangatlah penting guna mencapai good governance. Selain itu, perusahaan membutuhkan tata kelola IT yang baik sesuai dengan 5 area fokus tata kelola yaitu Strategic Alignment, Value Delivery, Performance Measurement, Risk Management dan Resource Management. Karena itu penting sekali bagi mahasiswa jurusan sistem informasi yang mempelajari matakuliah audit sistem informasi untuk dapat memahami dan mengerti setidaknya dasar dari materi tata kelola teknologi informasi, karena pada umumnya mahasiswa mempelajari materi ini melalui manual book, dan proses belajar di kelas sehingga dibutuhkannya sebuah media pembelajaran yang dapat memudahkan mahasiswa dalam mempelajari matakuliah audit sistem informasi terkhusus pada materi IT Governance atau tata kelola teknologi informasi secara mandiri.

Penulis melakukan pengujian menggunakan TAM. TAM (Technology Acceptance Model) di perkenalkan oleh Davis pada tahun 1985. Diadaptasi dari TRA (Theory of Reasoned Action) yang secara khusus disesuaikan untuk pemodelan penerimaan pengguna terhadap sistem informasi (Davis, Bagozzi and Warshaw, 1989). Terdapat 4 variabel pengujian pada TAM yaitu, Percived Usefulness, Percived Ease of Use, Attitude Toward Using, dan Actual System Use Namun penulis hanya melakukan pengujian terhadap persepsi kemudahan pengguna (Percived Ease of Use) sebagai batas pengujian. Adapaun alasan penulis mengambil pengujian tersebut, dikarenakan penulis ingin mengetahui bagaimana rancangan interface yang baik yang dapat memudahkan mahasiswa dalam menggunakan suatu aplikasi pembelajaran. Namun menurut Abdillah (2017), didalam bukunya yang berjudul "Metodologi Penelitan Terpadu Sistem Informasi" terdapat kritik terhadap persepsi kemudahan pengguna yang dikemukakan oleh Davis, Abdillah memaparkan beberapa jurnal penelitian yang menyanggah dan yang mendukung pengujian TAM. Abdillah menanyakan apakah persepsi kemudahan penggunaan yang berpengaruh signifikan terhadap persepsi terhadap kegunaan (Percived of Usefulness), berdasarkan temuan-temuan tersebut Abdillah menyimpulkan bahwa kedua persepsi model TAM adalah konstruk yang robust atau kuat dan telah terkonfirmasi dalam banyak studi empiris. Namun inkonsistensi hasil penelitian masih ditemukan di beberapa studi empiris. Oleh karena itu, pengujian kembali terhadap kedua persepsi TAM sebagai variabel prediktor dalam keputusan adopsi masih relevan. 


\section{Pembahasan}

\subsection{Hasil Rancangan Program}

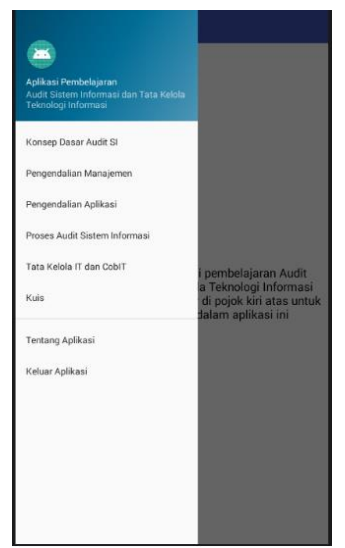

Gambar 2. Tampilan Menu Sliding Drawer

Pada halaman menu ini pengguna, dapat mencari materi yang tersedia di aplikasi pembelajaan audit sistem informasi dan tata kelola teknologi informasi berbasis mobile yang dibuat antara lain:

1. Konsep Dasar Audit SI (Gambar 3)

2. Pengendalian Manajemen

3. Pengendalian Aplikasi

4.Proses Audit Sistem Informasi

5.Tata Kelola IT dan CobIT

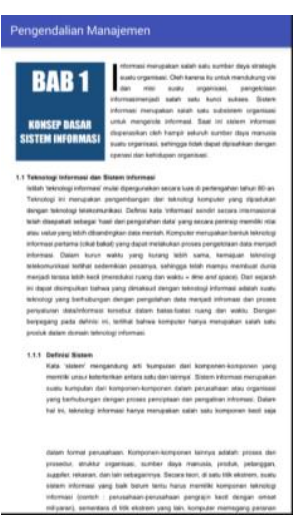

Gambar 3. Contoh Halaman Materi

Selain itu, terdapat menu kuis dan menu tentang aplikasi, yang mana menu kuis (Gambar 4) berisi 10 pertanyaan untuk evaluasi bagi mahasiswa/i yang sedang mempelajari matakuliah audit sistem informasi, sedangkan menu tentang aplikasi berisi tentang alasan, referensi, dan tujuan aplikasi ini dibuat.

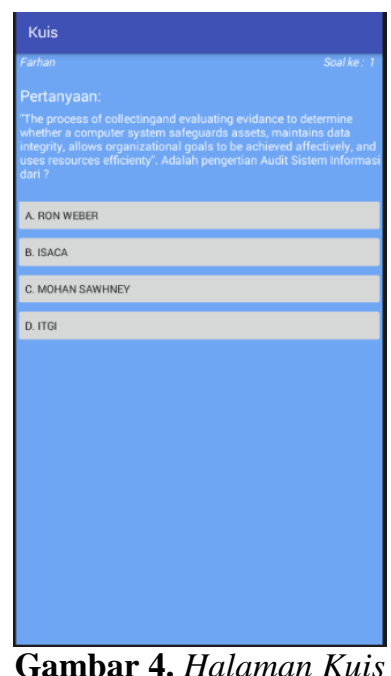

\subsection{Pengujian}

A. Populasi dan Teknik Pengambilan Sampel Populasi merupakan keseluruhan subjek atau totalitas subjek peneltian yang dapat berupa orang, benda, atau suatu yang dapat diperoleh atau dapat memberikan informasi (data) penelitian. Dengan kata lain, populasi adalah keseluruhan objek penelitian. Sedangkan sampel digunakan jika populasi yang diteliti besar dan peneliti tidak mungkin mempelajari seluruh populasi. Plihan pengambilan sampel antara lain karena keterbatasan biaya, tenaga, dan waktu yang dimiliki peneliti. Faktor yang perlu dipertimbangkan dalam pengambilan sampel adalah menentukan tujuan penelitian dan membatasi populasi (Arifin, 2017).

Adapun persamaan (1) yang digunakan penulis untuk menentukan sampel adalah sebagai berikut:

$n=\frac{N}{\left(1+N \cdot M o e^{2}\right)}$

Keterangan:

$\mathrm{n}$ adalah jumlah sampel, $\mathrm{N}$ jumlah populasi, dan Moe merupakan batas jumlah kesalahan terbesar atau maksimum (margin of error maximum).

Berdasarkan data presensi tahun ajaran 2017/2018, terdapat jumlah 345 mahasiswa/i yang mengambil matakuliah Audit Sistem Informasi di Program Studi Sistem Informasi, dari data populasi tersebut penulis melakukan perhitungan dengan menggunakan persamaan yang penulis paparkan sebelumnya dengan margin of error maximum sebesar 5\% atau 0,05, didapatkan hasil total sampel minimal adalah \pm 185 responden mahasiswa/i yang sudah mengambil matakuliah Audit Sistem Informasi di Program Studi Sistem Informasi, yang penulis berikan kuisioner secara online menggunakan Google Form.

B. Tahapan Pengujian

Tahapan pengujian merupakan proses pengujian terhadap aplikasi pembelajaran yang penulis buat. 
Pengujian dilakukan menggunakan TAM (Technology Acceptance Model) akan tetapi hanya terhadap 1 variabel pengujian yaitu pada Percived Ease of Use (persepsi terhadap kemudahan penggunaan) yang terdapat 6 indikator/instrumen yang akan dijadikan dasar pengujian. Terdapat 3 tahap pengujian yaitu, tahap pertama akan dilakaukan pengujian terhadap validitas dan reliabilitas instumen penelitian yang sebelumnya kuisioner/instrumen yang akan diuji telah disebar terlebih dahulu menggunakan Google Form yang juga dilampirkan file APK program, lalu tahap kedua akan dilakukan pengujian terhadap normalitas data dengan menggunakan kuisioner yang sama setalah hasil pengujian instumen penelitian, dan terakhir menghitung persentase hasil dari pengujian terhadap Percived Ease of Use (persepsi terhadap kemudahan penggunaan).

\section{Hasil Pengujian}

1. Uji Instrumen Penelitian

Pengujian yang dilakukan oleh penulis menggunakan aplikasi statistik SPSS versi 24.

a. Uji validitas

Validitas adalah kriteria utama keilmiahan suatu penelitian. Validitas menunjukan apakah hasil penelitian dapat diterima oleh khalayak dengan kriteria-kriteria tertentu. Penelitian empiris berusaha mengoptimalkan pencapaian validitas tersebut (Abdillah, 2017).

Valid tidaknya suatu suatu pertanyaan dalam kuisioner dilakukan dengan membandingkan nilai $r$ tabel dan nilai $r$ hitung. Nilai $r$ hitung adalah hasil olah data dengan korelasi Pearson. Sedangkan nilai $r$ tabel dapat dilihat pada tabel $r$ (Arifin, 2017). Ketentuan valid atau tidaknya suatu pertanyaan mengacu pada ketentuan sebagai berikut:

1. Jika $\mathrm{r}$ hitung $>\mathrm{r}$ tabel, maka perntanyaan dinyatakakn valid

2. Jika $r$ hitung $<\mathrm{r}$ tabel, maka pertanyaan dinyatakan tidak valid

Berikut adalah hasil pengujian yang penulis dapatkan, berdasarkan $r$ tabel maka nilai $r$ tabel dari 30 responden, dengan tingkat signifikansi two-tails dengan nilai 0.05 adalah:

$$
\mathrm{DF}=(185-2)=183=0,1213
$$

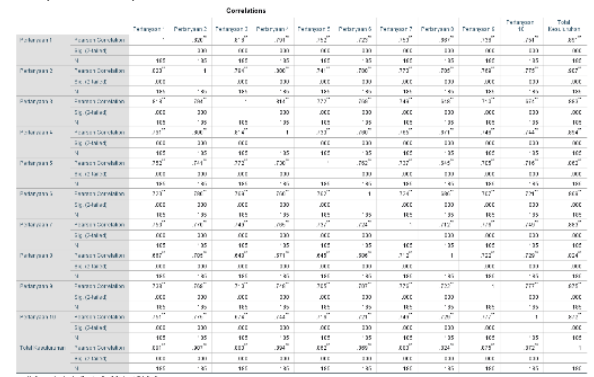

Gambar 5. Hasil Pengujian Validasi Kuisioner

Maka dengan hasil pengujian diatas dan berdasarkan ketentuan sebelumnya maka ke 10 kuisioner yang penulis ajukan mendapatkan hasil Valid. b. Uji reliabilitas

Reliabilitas menunjukan tingkat konsistensi dan stabilitas alat ukur atau instrumen penelitian dalam mengukur suatu konsep atau konstruk. Konsep reliabilitas sejalan dengan validitas konstruk atau kuantiatif. Konstruk valid sudah pasti reliabel, sebaliknya konstruk yang reliabel belum tentu valid. Konstruk dibandingkan reliabilitas. Ketika validitas konstruk tidak tercapai maka peneliti kemudian berharap setidaknya dapat mencapai reliabilitas (Abdillah, 2017).

Untuk mengetahui reabilitas pertanyaan adalah dengan melihat nilai Alpha (Conbach's Alpha) dibandingkan dengan nilai yang dipersyaratkan atau konstanta, yaitu 0,6 (Arifin, 2017). Ketentuan reliabel atatu tidaknya suatu pertanyaan mengacu pada ketentuan sebagai berikut:

1. Jika nilai Alpha > nilai Konstanta, maka pertanyaan dinyatakan reliabel

2. Jika nilai Alpha < nilai Konstanta, maka pertanyaan dinyatakan tidak reliabel

Berikut adalah hasil pengujian yang penulis dapatkan:

\section{Reliability Statistics}

\begin{tabular}{c|r}
$\begin{array}{c}\text { Cronbach's } \\
\text { Alpha }\end{array}$ & N of Items \\
\hline .966 & 10 \\
\hline Gambar 6. Hasil Nilai Alpha
\end{tabular}

Berdasarkan gambar 6 maka nilai Alpha yang didapat adalah 0.966 dan dengan ketentuan diatas, maka penulis menyimpulkan bahwasannya ke 10 kuisioner yang penulis ajukan mendapatkan hasil Reliabel.

\section{Uji Normalitas Data}

Uji normalitas merupakan uji yang mendasar sebelum melakukan analisis lebih lanjut. Data yang berdistibusi normal sering dijadikan landasan dalam beberapa uji statistik. Terdapat 3 tahapan pengujian yang penulis lakukan:

a. Metode Desktiptif

Dilakukan dengan menghitung dan melihat beberapa parameter untuk menentukan normalitas distribusi data berdasarkan koefisien varians, rasio skewness, dan rasio kurtosis (Arifin, 2017). Dengan rumus hitung sebagai berikut:

1. Varian digunakan sebagai salah satu deskriptor dispresi untuk distribusi data dan menggambarkan seberapa jauh suatu nilai terletak dari posisi rata-rata (Sarwono, 2015).

Koefisien varians dihitung dengan rumus:

(standar deviasi / mean) x $100 \%$, dengan ketentuan jika koefisien varians $<30 \%$ maka data berdistribusi normal atau mendekati normal. 
2. Skewness menggambarkan bagaimana poin-poin data pada posisi puncak atau bawah pada skala pengukuran (Sarwono, 2015).

Rasio skewness dihitung dengan rumus:

(skewness / standar error of skewness), dengan ketentuan jika rasio skewness $<2$ maka data berdistribusi normal atau mendekati normal.

3. Kurtosis menggambarkan bagaimana data terkonsentrasi di sekitar nilai tunggal biasnya nilai rata-rata. Kesimpulannya kurtosis mengukur ketinggian (peak) atau kerataan (flat) suatu distribusi data (Sarwono, 2015)

Rasio kurtosis dihitung dengan rumus:

(kurtosis / standar error of kurtosis), dengan ketentuan jika rasio skewness $<2$ maka data berdistribusi normal atau mendekati normal.

Berikut adalah hasil pengujian yang penulis dapatkan:

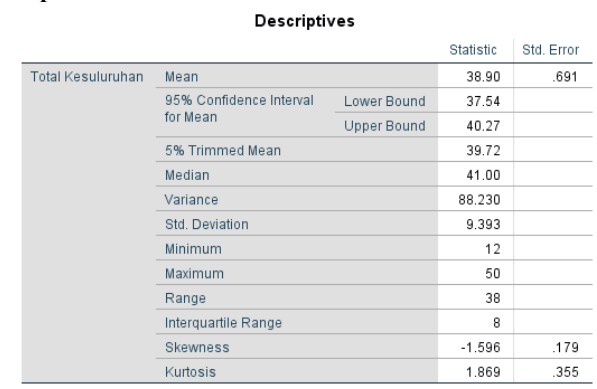

Gambar 7. Hasil Pengujian Deskriptif

1. Koefisien Varians:

$$
\left(\frac{9,393}{38,90}\right) \times 100 \%=0,241465=24 \%
$$

Sesuai dengan ketentuan diatas maka, data berdistribusi normal atau mendekati normal.

\section{Rasio Skweness}

$$
\left(\frac{-1,596}{0,179}\right)=-8,916
$$

Sesuai dengan ketentuan diatas maka, data berdistribusi normal atau mendekati normal.

\section{Rasio Kurtosis}

$$
\left(\frac{1,869}{0,355}\right)=5,265
$$

Sesuai dengan ketentuan diatas maka, data tidak berdistribusi normal atau tidak mendekati normal.

\section{b. Histogram}

Data dapat dikatakan berdistribusi normal atau mendekati normal jika gambar histogram menunjukan distribusi data yang cinderung normal (Arifin, 2017).
Berikut adalah hasil histogram yang penulis dapatkan:

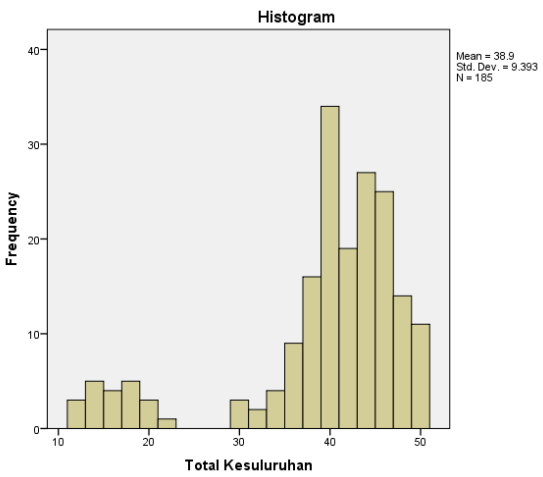

Gambar 8. Hasil Histogram

Dapat dilihat pada gambar 8 bahwa grafik histogram menunjukan meruncing kekanan tidak berbentuk seperti lonceng, maka dapat disimpulkan bahwasannya data tidak berdistribusi normal atau mendekati normal. Hal ini dikarenakan hasil perhitungan skewness dan kurtosis yang cenderung tidak berimbang yang disebabkan oleh banyaknya data ekstrim, yaitu data-data yang reratanya cenderung sama dibanding yang lain.

3. Uji Precived Ease of Use

Data variabel kemudahan diperoleh dari kuisioner terdiri dari 10 pernyataan menggunakan sekala penilaian likert, terdiri dari 5 alternatif jawaban, yaitu:

1. $\mathrm{SS}=$ Sangat Setuju (5)

2. $\mathrm{ST}=$ Setuju (4)

3. $\mathrm{RR}=$ Ragu-Ragu (3)

4. $\mathrm{TS}=$ Tidak Setuju (2)

5. STS $=$ Sangat Tidak Setuju (1)

Variabel ini memiliki skor ideal 925 sedangkan total skor ideal 9250. Hasil responden dapat dilihat pada tabel 1.

Tabel 1. Tanggapan Responden Berdasarkan

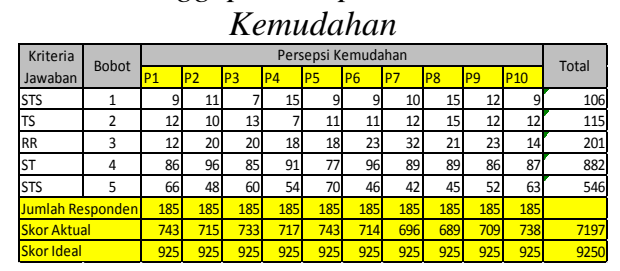

Setelah melakukan perhitungan skor pada kemudahan diperoleh nilai variabel sebesar $=7197$.

Perhitungan persentase skor aktual berdasarkan tabel data tanggapan responden berdasarkan persepsi kemudahan, yaitu :

$$
\begin{aligned}
& \text { Persentase penerimaan } \\
& =\frac{\text { skor aktual }}{\text { skor ideal }} \times 100 \% \quad \text { (Davis, } \\
& =\frac{7197}{9250} \times 100 \%=0,7780 \\
& =78 \%
\end{aligned}
$$


Sehingga didaptkan kesimpulan $78 \%$ responden raguragu bahwa aplikasi pembelajaran audit sistem informasi dan tata kelola teknologi informasi berbasis mobile yang penulis buat mudah untuk digunakan

\section{Kesimpulan}

Berdasarkan uraian yang telah dipaparkan, maka dapat diambil kesimpulan sebagai berikut:

1. Aplikasi yang dirancang dan dibuat yaitu aplikasi pembelajaran pada matakuliah audit sistem informasi ternyata dapat membantu mahasiswa dalam mempelajari materi dasar tata kelola teknologi informasi berbasis mobile dikarenakan:

a. Aplikasi yang penulis buat merupakan aplikasi offline yang tidak membutuhkan koneksi internet, sehingga dapat digunakan kapanpun diamanapun.

b. Konten aplikasi yang penulis buat berdasarkan buku referensi yang ditulis oleh Gondodiyoto (2007), sehingga materi yang dipelajari oleh pengguna dapat dipertanggung jawabkan.

2. Berdasarkan hasil pengujian yang penulis lakukan didapatkan sebuah hasil bahwasannya instrument penelitian yang penulis paparkan terbukti valid dan reliable, akan tetapi dalam pengujian normalitas data, data sebaran yang dihasilkan dari kuisioner/instrument penelitian didapakan hasil data terdistribusi tidak mendekati normal, hal ini dikarenakan hasil perhitungan skewness dan kurtosis yang cenderung tidak berimbang yang disebabkan oleh banyaknya data ekstrim, yaitu data-data yang rata-ratanya cenderung sama dibandingkan yang lain, sehingga perlu adanya penelitian lebih lanjut terhadap hasil pengujian instrumen penelitian.

3. Berdasarkan pengujian Persepsi Kemudahan (Percived Ease of Use) didapatkan kesimpulan bahwa $78 \%$ responden ragu terhadap aplikasi pembelajaran audit sistem informasi dan tata kelola teknologi informasi berbasis mobile yang dibuat karena kurang memudahkan pengguna.

\section{Daftar Pustaka}

Abdillah, W. (2017) Metode Penelitian Terpadu Sistem Informasi Pemodelan Toeretis, Pengukuran, dan Penujian Statis. Edited by I. R. Utami. Yogyakarta: Penerbit ANDI.

Arifin, J. (2017) SPSS24 Untuk Penelitian dan Skripsi. Jakarta: PT Elex Media Komputindo.

Chee, K. N. et al. (2017) 'Review of Mobile Learning Trends 2010-2015: A Meta-Analysis', Journal of Educational Technology \& Society, 20(2), pp. 113126.

Davis, F. D. (1985) 'A Technology Acceptance Model For Empirically Testing New End-User Information Systems: Theory And Results', Industrial Enginering, p. 291.

Davis, F. D., Bagozzi, R. P. and Warshaw, P. R. (1989) 'User Acceptance of Computer Techology A Comparison of Two Theoretical Models', Management Science. San Luis Obispa, California, 35 , p. 22.
Gondodiyoto, S. (2007) Audit Sistem Informasi + Pendekatan CobIT. Revisi. Edited by H. Hendarti. Jakarta: Mitra Wacana Media.

Marghescu, G., Chicioreanu, T. D. and Marghescu, I. (2007) 'An Alternative to the Traditional Methods in Education - M-Learning: a Glance into the Future', EUROCON The Internation Conference on 'computer as a Tool', pp. 2410-2414.

Mulyawan, S. and Budiman, A. (2013) 'Perancangan Aplikasi Pembelajaran Tentang Tindak Pidana Korupsi Berbasis Mobile', Seminar Nasional Teknologi Informasi dan Komunikasi 2013 (SENTIKA 2013), (February), pp. 46-51.

Ozuorcun, N. C. and Tabak, F. (2012) 'Is M-learning Versus E-learning or are They Supporting Each Other?', Procedia - Social and Behavioral Sciences, 46, pp. 299-305.

Sarwono, J. (2015) Rumus-Rumus Populer dalam SPSS 22 untuk Riset Skripsi. Edited by A. Sahala. Yogyakarta: Penerbit ANDI.

Universitas Teknokrat Indonesia (2017) PEDOMAN AKADEMIK KURIKULUM 2017. Lampung: Universitas Teknokrat Indonesia. 